\title{
Net anthropogenic nitrogen inputs (NANI) index application in Mainland China
}

\author{
Yuguo Han ${ }^{\text {a,* }}$, Yuntao Fan ${ }^{\mathrm{b}}$, Peiling Yang ${ }^{\mathrm{c}}$, Xiaoxue Wang ${ }^{\mathrm{d}}$, Yujie Wang ${ }^{\mathrm{a}}$, Jinxia Tian ${ }^{\mathrm{e}}$, \\ Lei $\mathrm{Xu}^{\mathrm{f}}$, Chengzhi Wang ${ }^{\mathrm{g}}$ \\ a School of Soil and Water Conservation, Beijing Forestry University, Beijing 100083, China \\ b Chinese Academy of Agricultural Mechanization Sciences, Beijing 100083, China \\ c College of Water Resources and Civil Engineering, China Agricultural University, Beijing 100083, China \\ d State Key Laboratory of Urban and Regional Ecology, Research Center for Eco-Environmental Sciences, Chinese Academy of Sciences, Beijing 100085, China \\ e Beijing Water Technology Center, Beijing 100073, China \\ ${ }^{\mathrm{f}}$ China Irrigation and Drainage Development Center, Beijing 100054, China \\ ${ }^{g}$ ChaoYang Water Affairs Bureau, Beijing 100026, China
}

\section{A R T I C L E I N F O}

Article history:

Received 17 October 2012

Received in revised form 12 July 2013

Accepted 24 July 2013

Available online 7 September 2013

\section{Keywords:}

Anthropogenic

Nitrogen input

Atmospheric $\mathrm{N}$ deposition

Seeding nitrogen

Nitrogen fertilizer use

$\mathrm{N}$ fixation

\begin{abstract}
A B S T R A C T
This study provides a new understanding to sources of nitrogen $(\mathrm{N})$, and may serve as a foundation for further exploration of anthropogenic effects on $\mathrm{N}$ inputs. Estimation of net anthropogenic nitrogen inputs (NANI) was based on an inventory of atmospheric $\mathrm{N}$ deposition, $\mathrm{N}$ fertilizer use, $\mathrm{N}$ in human food and animal feed, seeding $\mathrm{N}$ and $\mathrm{N}$ fixation. This study took a step forward to calculate NANI in detail on a regional scale, and analyzed its temporal variations and geographic differences. Over the past 28 years, NANI increased significantly in Mainland China, from $2360 \mathrm{~kg} \mathrm{~N} \mathrm{~km}^{-2} \mathrm{yr}^{-1}$ to $5013 \mathrm{~kg} \mathrm{~N} \mathrm{~km}^{-2} \mathrm{yr}^{-1}$. On a geographical basis, NANI was higher in southeast where China's eight major watersheds are located than in northwest, and the largest NANI, $26160 \mathrm{~kg} \mathrm{~N} \mathrm{~km}^{-2} \mathrm{yr}^{-1}$, appeared in Shanghai. The administrative regions corresponding to Haihe watershed, Huaihe watershed and Tai lake watershed have the largest NANI. N input of fertilizer is the largest source of NANI, followed by atmospheric $\mathrm{N}$ deposition and $\mathrm{N}$ fixation. The primary factor in relation to the change in NANI is total population density, followed by cultivated land area and total grain yield. In those densely populated large cities and watersheds, reasonably allocating the social resources to reduce the existing population density is the most effective way to address the problem of high $\mathrm{N}$ inputs, while in those agriculturedominated regions and watersheds, the most effective way for reducing NANI is to improve fertilizer utilization efficiency in agriculture.
\end{abstract}

(C) 2013 Elsevier B.V. All rights reserved.

\section{Introduction}

China is one of the countries in the world with rapidest population and economy growth. In the past thirty years, population and economy growth bring about many environmental problems (Hu et al., 2011; Wu et al., 2011). The nutrient pollution is the most serious one. Even though some technology has been used to control nutrient pollution, the effect is imperceptible because the control is merely focused on end-control engineering projects, such as establishment of sewage farm and artificiallyreclaim of wetland at bayou or watercourse (Guan et al., 2011; Liu et al., 2010). Therefore, it is essential to investigate the pollutant sources and find strategies to control these sources.

Eutrophication is a kind of water pollution caused by excessive nutrients. Nitrogen $(\mathrm{N})$ is one of the main pollution elements of eutrophication. $\mathrm{N}$ emission from different pathways and sources is a key issue concerning the protection of water quality and sustainable watershed

\footnotetext{
* Corresponding author. Tel./fax: + 861062336324

E-mail address: yghan@bjfu.edu.cn (Y. Han).
}

management practices (Lowrance et al., 1985; Neset et al., 2008; Rivera et al., 2007).

The nutrient input to the watershed is mainly caused by human activities (Leeben et al., 2008), such as crop cultivation, livestock breeding, human excretion, household garbage and so on. Many researchers have drawn their attention to the evaluation of pollutant loadings by human activities. Jordan and Weller (1996) put forth the concept of net anthropogenic nitrogen inputs (NANI), which refers to the sum of the total amount of $\mathrm{N}$ derived from applied fertilizer, $\mathrm{N}$ fixation and atmospheric deposition and the total amount of $\mathrm{N}$ exported from food and feed in the watershed ecosystem. The study of McIsaac et al. (2001) shows that NANI is more sensitive to the $\mathrm{N}$ flux in the watershed, i.e. a slight change in NANI may result in a great change in riverine $\mathrm{N}$ content. Russell et al. (2008) also conducted a relevant investigation on net anthropogenic phosphorus inputs (NAPI), pointing out that NAPI is an important indicator of $\mathrm{P}$ pollution in watershed. The theories provide useful research methods for investigation on nutrient inputs (Bristow et al., 2008; Han et al., 2011). However, few of them pay sufficient attention to $\mathrm{N}$ in seed in their calculation of anthropogenic nitrogen. Therefore, we 
introduced a comparatively reasonable way of studying $\mathrm{N}$ inputs by taking $\mathrm{N}$ in seed into consideration, that is, NANI = atmospheric $\mathrm{N}$ deposition $+\mathrm{N}$ fertilizer use + seeding $\mathrm{N}+\mathrm{N}$ in human food and animal feed $+\mathrm{N}$ fixation. Ti et al. (2012) studied $\mathrm{N}$ budget in mainland China and its impact on environment, but analysis on $\mathrm{N}$ sources and their change was insufficient, so they lacked deep understanding to the fate of accumulated $\mathrm{N}$ and did not mention the solution to high level of N. With NANI as a starting point, we conducted the following studies: (a) researching the spatial distribution and temporal variation of net $\mathrm{N}$ input; (b) analyzing the main sources of net $\mathrm{N}$ inputs and their change, and proposing the strategies for reducing NANI in different areas (those densely populated urban areas and those rural areas with more fertilizer application, etc.); and (c) discussing the relationship between typical socioeconomic factors and net $\mathrm{N}$ input. To some extent, this paper overcomes the difficulties in quantifying $\mathrm{N}$ sources and introduces a more reasonable way for studying $\mathrm{N}$ inputs.

\section{Methods}

\subsection{Study sites}

China is situated at $4^{\circ}$ to $53^{\circ} 30^{\prime}$ North Latitude and $73^{\circ} 40^{\prime}$ to $135^{\circ} 05^{\prime}$ East Longitude and composed of 23 provinces, 5 autonomous regions, 4 municipalities and 2 special administrative regions. The study region in this paper is Mainland China, namely, Taiwan province, Hongkong and Macao special administrative regions are excluded. Therefore, with each administrative region as a research unit, there are 31 research units in total as shown in Fig. 1 and Table 1.
We obtained the data from the National Bureau of Statistics of China. Land cover was derived from satellite images of Ministry of Land and Resources of China. We calculated net N input values for years 1981, 1990, 2000 and 2009.

\subsection{NANI estimation}

NANI was estimated by accounting for the anthropogenic $\mathrm{N}$ inputs in each unit. We quantified $\mathrm{N}$ inputs in each unit, most of which is derived from human activities: Net atmospheric $\mathrm{N}$ deposition, fertilizer use, seeding N, human food and animal feed, and N fixation (see Fig. 2).

\subsubsection{Atmospheric $N$ deposition}

Atmospheric deposition includes dry deposition and wet deposition. Atmospheric $\mathrm{N}$ deposition in this paper includes both of them. Ti (2011) calculated the value of atmospheric $\mathrm{N}$ deposition in different districts of Mainland China between 1985 and 2007. Based on Ti Chaopu's conclusion, values of atmospheric $\mathrm{N}$ deposition were calculated in this paper by mean deviation for years 1981, 1990, 2000 and 2009 (see Table 1).

Atmospheric $\mathrm{N}$ deposition is associated with fertilizer use and human and animal $\mathrm{N}$ excretion. To avoid duplicating $\mathrm{N}$ inputs, all emitted and redeposited $\mathrm{N}$ has been excluded (Asman et al., 1998; Hutchings et al., 2001). Thus, we estimated volatilization losses as a percentage of each applied fertilizer as (see 'input: nitrogenous fertilizer use'): $15 \%$ of urea, $2 \%$ of ammonium nitrate, $2.5 \%$ of ammonium bicarbonate, $0.1 \%$ of anhydrous ammonia, and $2 \%$ of other combined fertilizers (Battye et al., 1994). Human and animal N excretion is 2\% (Battye et al., 1994; Su et al., 2005; Yang et al., 2010).

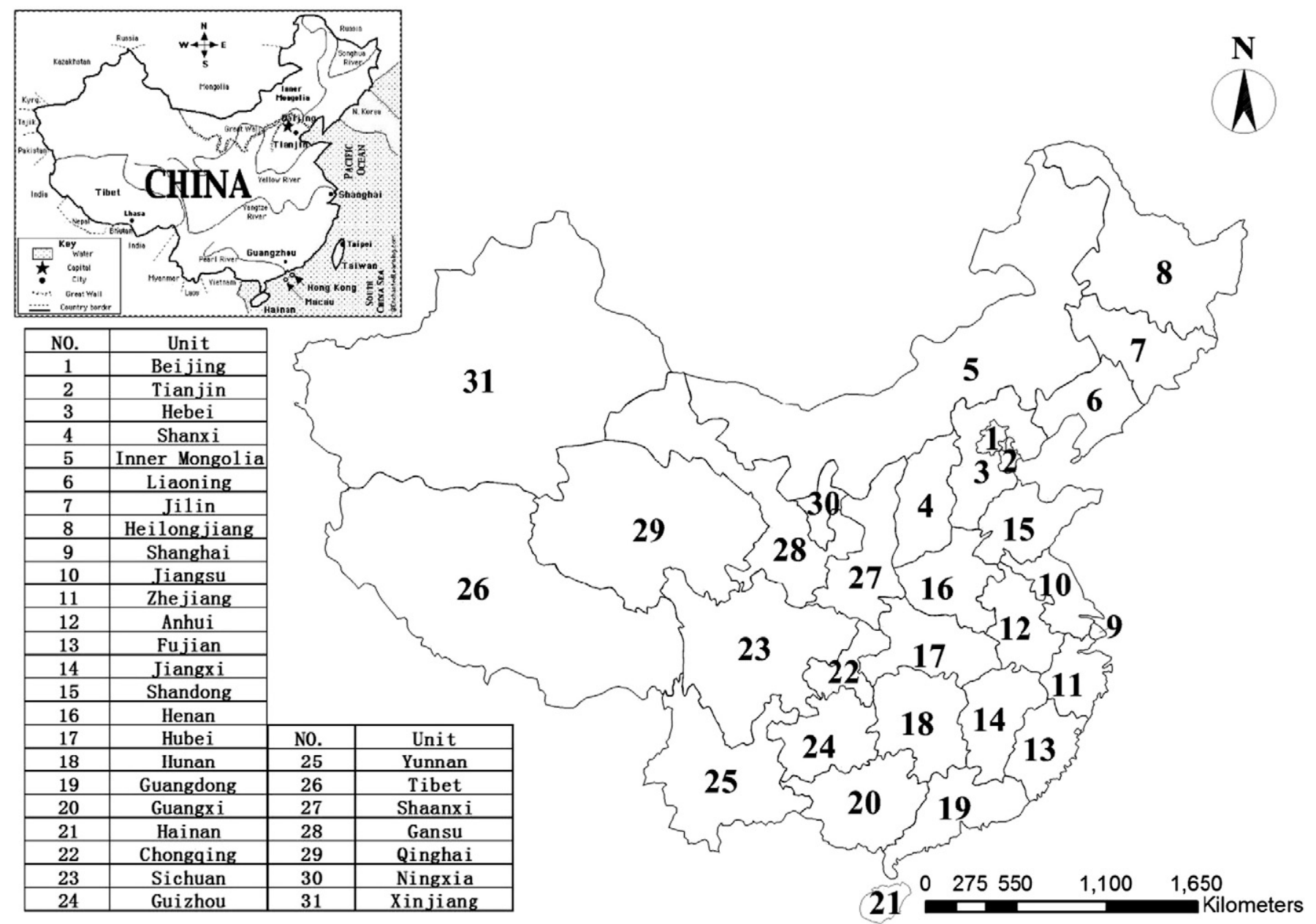

Fig. 1. Geographic location of Mainland China and distribution of 31 research units. 
Table 1

Characteristics of Mainland China in 2010 and atmospheric N deposition in difference years $\left(\mathrm{kg} \mathrm{N} \mathrm{km}^{-2} \mathrm{yr}^{-1}\right)$.

\begin{tabular}{|c|c|c|c|c|c|c|}
\hline & \multicolumn{2}{|c|}{$\begin{array}{l}\text { Characteristics of Mainland China } \\
\text { in } 2010\end{array}$} & \multicolumn{4}{|c|}{$\begin{array}{l}\text { Atmospheric } \mathrm{N} \text { deposition } \\
\text { in difference years } \\
\left(\mathrm{kg} \mathrm{N} \mathrm{km}^{-2} \mathrm{yr}^{-1}\right)\end{array}$} \\
\hline & $\begin{array}{l}\text { Area } \\
\text { (ten thousands } \mathrm{km}^{2} \text { ) }\end{array}$ & $\begin{array}{l}\text { Population } \\
\text { (ten thousands) }\end{array}$ & 1981 & 1990 & 2000 & 2009 \\
\hline Beijing & 1.68 & 1755.00 & 1584 & 2133 & 2742 & 3291 \\
\hline Tianjin & 1.13 & 1228.16 & 1327 & 2117 & 2994 & 3784 \\
\hline Hebei & 19.00 & 7034.40 & 954 & 1386 & 1866 & 2298 \\
\hline Shanxi & 15.60 & 3427.36 & 1443 & 2072 & 2772 & 3401 \\
\hline $\begin{array}{l}\text { Inner } \\
\text { Mongolia }\end{array}$ & 118.30 & 2422.07 & 262 & 385 & 522 & 645 \\
\hline Liaoning & 14.57 & 4319.00 & 1657 & 2077 & 2544 & 2964 \\
\hline Jilin & 18.70 & 2739.55 & 1046 & 1353 & 1693 & 1999 \\
\hline Heilongjiang & 46.90 & 3826.00 & 412 & 549 & 700 & 837 \\
\hline Shanghai & 0.62 & 1921.00 & 3785 & 4827 & 5986 & 7029 \\
\hline Jiangsu & 10.26 & 7725.00 & 2541 & 3296 & 4135 & 4890 \\
\hline Zhejiang & 10.18 & 5180.00 & 2536 & 2850 & 3200 & 3514 \\
\hline Anhui & 13.90 & 6131.00 & 1359 & 1802 & 2295 & 2739 \\
\hline Fujian & 12.00 & 3627.00 & 1302 & 1675 & 2089 & 2462 \\
\hline Jiangxi & 16.66 & 4432.16 & 1327 & 1712 & 2139 & 2524 \\
\hline Shandong & 15.30 & 9470.30 & 2016 & 2592 & 3231 & 3806 \\
\hline Henan & 16.70 & 9487.00 & 1406 & 2130 & 2935 & 3659 \\
\hline Hubei & 18.74 & 5720.00 & 1183 & 1559 & 1978 & 2354 \\
\hline Hunan & 21.00 & 6406.00 & 900 & 1244 & 1626 & 1969 \\
\hline Guangdong & 18.60 & 9638.00 & 2008 & 2558 & 3170 & 3721 \\
\hline Guangxi & 23.63 & 4856.00 & 998 & 1470 & 1995 & 2466 \\
\hline Hainan & 3.40 & 864.07 & 820 & 1329 & 1895 & 2404 \\
\hline Chongqing & 8.20 & 2859.00 & 1081 & 1658 & 2299 & 2875 \\
\hline Sichuan & 48.80 & 8185.00 & 1458 & 1766 & 2109 & 2418 \\
\hline Guizhou & 17.00 & 3798.00 & 864 & 1168 & 1506 & 1810 \\
\hline Yunnan & 39.40 & 4571.00 & 648 & 946 & 1277 & 1575 \\
\hline Tibet & 122.00 & 290.03 & 25 & 50 & 77 & 102 \\
\hline Shaanxi & 20.50 & 3772.00 & 1537 & 2070 & 2662 & 3194 \\
\hline Gansu & 45.00 & 2635.46 & 604 & 787 & 991 & 1174 \\
\hline Qinghai & 72.00 & 557.30 & 478 & 491 & 506 & 519 \\
\hline Ningxia & 6.64 & 625.20 & 793 & 1218 & 1690 & 2116 \\
\hline Xinjiang & 160.00 & 2158.63 & 95 & 147 & 205 & 257 \\
\hline $\begin{array}{l}\text { Mainland } \\
\text { China }\end{array}$ & 956.41 & 131660.69 & 677 & 898 & 1142 & 1363 \\
\hline
\end{tabular}

\subsection{2. $N$ fertilizer use}

Current management practices in agricultural production are highly dependent on intensive fertilizer use, so fertilizer use is one of the important sources of NANI. Estimates of fertilizer application are available for each subunit (data from National Bureau of Statistics of China), broken down by type: ammonium nitrate, anhydrous ammonia, ammonium bicarbonate, urea, and miscellaneous forms. Then we estimated volatilization losses as a percentage of applied fertilizers and aggregated the

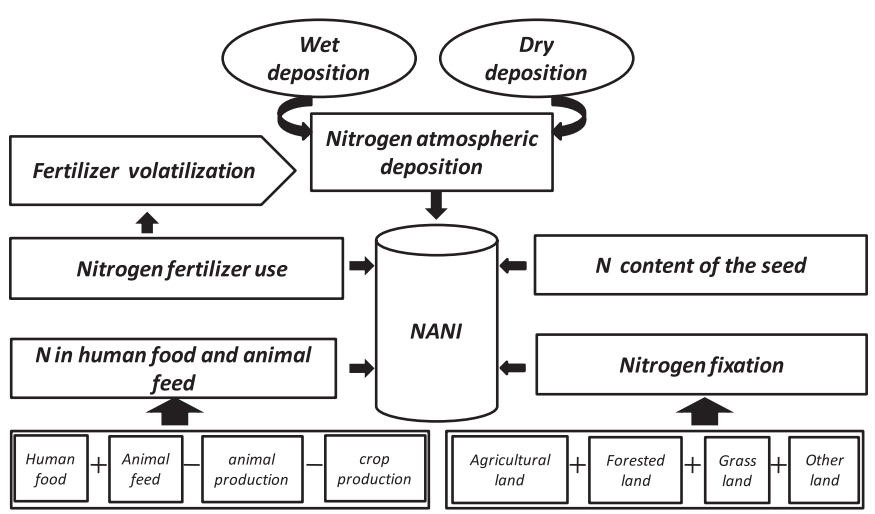

NANA $=\mathbf{N}$ atmospheric deposition $+\boldsymbol{N}$ fertilizer use $+\boldsymbol{N}$ in human food and animal feed + $N$ fixation $+N$ seed subunit-level fertilizer data using GIS software by weighting each subunit's data. N content in different fertilizers is: $46 \%$ in urea, $35 \%$ in ammonium nitrate, $17 \%$ in ammonium bicarbonate, $82.3 \%$ in anhydrous ammonia, and $12.8 \%$ in other combined fertilizers (Liang, 1999).

\subsubsection{Seeding $N$}

We chose vegetable and 7 main agricultural crops to estimate seeding $\mathrm{N}$ in each research unit. The vegetable was represented by cabbage because the value of seeding $\mathrm{N}$ was slightly different between different vegetable species. Seeding $N$ per unit area for each crop type has been reported by Agricultural Technology Promotion Center of China (1999) as shown in Table 2. The data on the cultivated area of each crop type were obtained from the National Bureau of Statistics of China. Seeding N was estimated by multiplying the seeding $\mathrm{N}$ input per unit area for each crop type by the cultivated area of the research unit.

\subsubsection{Net $N$ input in human food and animal feed}

Human and animal require a great deal of food and feed during their lives, so net $\mathrm{N}$ in human food and animal feed is also an important source of NANI. Human food and animal feed are associated with input/output $\mathrm{N}$ of agricultural products. We used the method introduced by Jordan and Weller (1996) (Han et al., 2013; Russell et al., 2008), who quantified the net input of $\mathrm{N}$ as: net input in food and feed $=$ food and feed consumption of human and animal - animal production for human consumption - crop production.

We obtained data on human population as well as crop products and animal products from the National Bureau of Statistics of China. Each item, with the final result, in this calculation is presented by research unit data.

2.2.4.1. Food and feed consumption. Human consumption of $\mathrm{N}$ in food was estimated by multiplying the number of inhabitants by the N consumption per capita. $\mathrm{N}$ consumption per capita per year was calculated based on food consumption per capita that was obtained from the National Bureau of Statistics. By calculating N content in main human food, we obtained that $\mathrm{N}$ consumption per capita per year was $3.92 \mathrm{~kg}$, $4.67 \mathrm{~kg}$, $4.75 \mathrm{~kg}$ and $4.58 \mathrm{~kg}$ in 1981, 1990, 2000, and 2009, respectively.

Animal consumption of $\mathrm{N}$ was obtained by multiplying the number of each animal species by $\mathrm{N}$ consumption of individual. We chose the consumption values as reported by $\mathrm{Wu}$ (2005) and the values of the percentage N excreted as reported by Van (1998) (see Table 3). We assumed all animals were completely formula fed, i.e., $50 \%$ from corn and $50 \%$ from pasture ( $\mathrm{Li}, 2007)$.

2.2.4.2. Crop production. We chose vegetable and 14 main agricultural crops to estimate $\mathrm{N}$ production in each research unit. The vegetable was represented by cabbage because nitrogen content was slightly different between different vegetable species. We calculated $\mathrm{N}$ content in the crop harvest in each research unit. $\mathrm{N}$ content $\left(\mathrm{g} \cdot \mathrm{kg}^{-1}\right)$ in each crop type has been reported by Wang (2003) as shown in Table 4. We assumed that pests, spoilage, and processing caused 10\% loss for all crops (Da, 2013; Hu et al., 2012; Zheng, 2011).

Table 2

Input of seeding $\mathrm{N}$.

\begin{tabular}{llc}
\hline Seed & Seeding $\mathrm{N}\left(\mathrm{g} \cdot \mathrm{kg}^{-1}\right)$ & Seeding $\mathrm{N}\left(\mathrm{kg} \cdot \mathrm{km}^{-2}\right)$ \\
\hline Paddy & 19.1 & 69.2 \\
Wheat & 28.2 & 227.1 \\
Corn & 14.3 & 25.9 \\
Soybeans & 59.2 & 107.5 \\
Broomcorn & 16.64 & 30.1 \\
Peanuts & 19.36 & 35.2 \\
Cotton & 30.4 & 5.8 \\
Vegetables & 33.6 & 2.8 \\
\hline
\end{tabular}


Table 3

Animal N consumption and excretion (Van, 1998; Wu, 2005).

\begin{tabular}{|c|c|c|c|c|}
\hline Animal species & 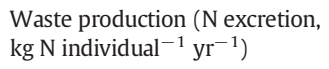 & Percent excreted & $\begin{array}{l}\text { Consumption ( } \mathrm{N} \text { intake rate, } \\
\mathrm{kg} \mathrm{N} \text { individual }^{-1} \mathrm{yr}^{-1} \text { ) }\end{array}$ & $\begin{array}{l}\text { Animal production } \\
\left(\mathrm{kg} \mathrm{N}_{\text {individual }}^{-1} \mathrm{yr}^{-1}\right)\end{array}$ \\
\hline Hogs and pigs & 11.51 & 69 & 16.68 & 5.17 \\
\hline Horses and cattle & 48.79 & 89 & 54.82 & 6.03 \\
\hline Chickens & 0.37 & 65 & 0.57 & 0.20 \\
\hline Ducks & 0.41 & 65 & 0.63 & 0.22 \\
\hline Sheep and lambs & 5.75 & 84 & 6.85 & 1.10 \\
\hline
\end{tabular}

2.2.4.3. Animal production. Animal N production includes meat, milk, eggs, etc. We estimated animal $\mathrm{N}$ production as the difference between animal feed consumption (intake) and animal excretion (waste production). We assumed that spoilage and inedible components caused $10 \%$ loss of animal products available for consumption.

\subsection{5. $N$ fixation}

Depletion of soil $\mathrm{N}$ in agriculture occurs primarily through plant $\mathrm{N}$ uptake. This is often replenished through fertilizer $\mathrm{N}$ additions, or, at least in part through natural processes, the most important of which is biological $\mathrm{N}$ fixation (BNF). It has been estimated that on a global scale, BNF may contribute some 90 million tons $\mathrm{ha}^{-1} \mathrm{yr}^{-1}$ to agricultural systems (Bohlool et al., 1992). Burns and Hardy (1975) estimated BNF based on different land types (Dou, 1989) as $500 \mathrm{~kg} \mathrm{~N} \mathrm{~km}^{-2} \mathrm{yr}^{-1}$, $1000 \mathrm{~kg} \mathrm{~N} \mathrm{~km}^{-2} \mathrm{yr}^{-1}, 1500 \mathrm{~kg} \mathrm{~N} \mathrm{~km}^{-2} \mathrm{yr}^{-1}, 0 \mathrm{~kg} \mathrm{~N} \mathrm{~km}^{-2} \mathrm{yr}^{-1}$ and $100 \mathrm{~kg} \mathrm{~N} \mathrm{~km}^{-2} \mathrm{yr}^{-1}$ for agricultural land, forest land, grass land, developed land and other land, respectively. Total $\mathrm{N}$ fixation in each subunit was derived by multiplying the value of fixation for each land cover type by its area. The data on the areas of agricultural land, forest land, grass land, developed land and other land came from the National Bureau of Statistics of China and satellite images of Ministry of Land and Resources of China.

\subsection{Data analysis}

Based on atmospheric $\mathrm{N}$ deposition, $\mathrm{N}$ fertilizer use, $\mathrm{N}$ in human food and animal feed, seeding $\mathrm{N}$ and $\mathrm{N}$ fixation, NANI was calculated by summing the values of these $\mathrm{N}$ sources in all research units within Mainland China. Geographic and spatial analysis of NANI was conducted using average NANI values of the 31 research units in years 1981, 1990, 2000 and 2009. The land cover data was analyzed with the ArcInfo 9.3 (ESRI Inc.) geographic information system to calculate the proportion of row crops and forest in each unit, and the number of animals in each unit was calculated from agricultural census data. We also investigated the change in NANI and in the sources of NANI between different

Table 4

$\mathrm{N}$ content in agricultural crop products (Wang, 2003).

\begin{tabular}{lc}
\hline Crop & $\mathrm{N}\left(\mathrm{g} \mathrm{kg}^{-1}\right)$ \\
\hline Corn & 14.08 \\
Wheat & 17.92 \\
Soybean & 56.16 \\
Paddy & 11.84 \\
Millet & 14.40 \\
Broomcorn & 16.64 \\
Peanut & 19.36 \\
Potato & 3.20 \\
Chestnut & 6.72 \\
Apple & 0.32 \\
Grape & 0.80 \\
Peach & 0.80 \\
Pear & 0.48 \\
Watermelon & 2.46 \\
Vegetable & 2.72 \\
\hline
\end{tabular}

years. Grey relational grade analysis was conducted between the socioeconomic factors (gross domestic product, gross agricultural output value, cultivated land area, total population density, agricultural population density, the total fertilizer, total population and total grain yield) and the NANI calculation.

\section{Results}

\subsection{Temporal variation of NANI}

Table 5 shows NANI in different years in Mainland China. Across Mainland China, the largest NANI value $\left(5013 \mathrm{~kg} \mathrm{~N} \mathrm{~km}^{-2} \mathrm{yr}^{-1}\right)$ appeared in 2009. Over the past 28 years, NANI had an upward trend in all of these 31 research units, implying a rising trend in population growth and economic development. Cultivated area in Mainland China increased from $9.9 \times 10^{5} \mathrm{~km}^{2}$ to $12.2 \times 10^{5} \mathrm{~km}^{2}$, fertilizer use quantity increased from $133.49 \times 10^{5}$ ton to $539.06 \times 10^{5}$ ton and meanwhile population grew from $9.96 \times 10^{8}$ to $13.17 \times 10^{8}$. Therefore, NANI was also rising. As for NANI in different research units, Henan (15941 $\mathrm{kg} \mathrm{N} \mathrm{km}^{-2} \mathrm{yr}^{-1}$ ) had the greatest change over the last

Table 5

NANI of different research units in different years.

\begin{tabular}{|c|c|c|c|c|c|}
\hline \multirow[t]{2}{*}{ Name } & \multicolumn{5}{|c|}{ NANI $\left(\mathrm{kg} \mathrm{N} \mathrm{km}^{-2} \mathrm{yr}^{-1}\right)$} \\
\hline & 1981 & 1990 & 2000 & 2009 & 2009-1981 \\
\hline Beijing & 7148 & 9836 & 13062 & 12668 & 5520 \\
\hline Tianjin & 5437 & 7915 & 14726 & 19568 & 14131 \\
\hline Hebei & 4487 & 7258 & 11406 & 12256 & 7769 \\
\hline Shanxi & 3681 & 5307 & 6916 & 7581 & 3900 \\
\hline Inner Mongolia & 1091 & 1310 & 1608 & 2117 & 1026 \\
\hline Liaoning & 5384 & 6940 & 8716 & 9414 & 4030 \\
\hline Jilin & 2732 & 4442 & 5919 & 6834 & 4102 \\
\hline Heilongjiang & 1472 & 1650 & 2148 & 2306 & 834 \\
\hline Shanghai & 21125 & 27919 & 30734 & 24896 & 3771 \\
\hline Jiangsu & 10236 & 17457 & 23419 & 24219 & 13983 \\
\hline Zhejiang & 7044 & 9943 & 10110 & 10964 & 3920 \\
\hline Anhui & 5108 & 8777 & 12284 & 13121 & 8013 \\
\hline Fujian & 4123 & 6241 & 8217 & 8501 & 4378 \\
\hline Jiangxi & 3462 & 5145 & 6073 & 6608 & 3146 \\
\hline Shandong & 8712 & 13241 & 18285 & 18072 & 9360 \\
\hline Henan & 5149 & 11054 & 16610 & 21090 & 15941 \\
\hline Hubei & 3882 & 7055 & 10292 & 12756 & 8874 \\
\hline Hunan & 4162 & 5484 & 7163 & 8511 & 4349 \\
\hline Guangdong & 6221 & 9210 & 10508 & 13115 & 6894 \\
\hline Guangxi & 3122 & 4530 & 5981 & 7196 & 4074 \\
\hline Hainan & 3057 & 4753 & 7289 & 9793 & 6736 \\
\hline Chongqing & 4448 & 7016 & 8797 & 10103 & 5655 \\
\hline Sichuan & 3360 & 4582 & 5548 & 6227 & 2867 \\
\hline Guizhou & 2821 & 3984 & 5214 & 6035 & 3214 \\
\hline Yunnan & 2016 & 2940 & 4160 & 5161 & 3145 \\
\hline Tibet & 760 & 788 & 823 & 870 & 110 \\
\hline Shaanxi & 3266 & 5257 & 7539 & 8855 & 5589 \\
\hline Gansu & 1689 & 2245 & 2716 & 3173 & 1484 \\
\hline Qinghai & 1292 & 1323 & 1329 & 1351 & 59 \\
\hline Ningxia & 2236 & 3684 & 5495 & 6765 & 4529 \\
\hline Xinjiang & 851 & 995 & 1195 & 1405 & 554 \\
\hline Mainland China & 2360 & 3388 & 4401 & 5013 & 2653 \\
\hline
\end{tabular}



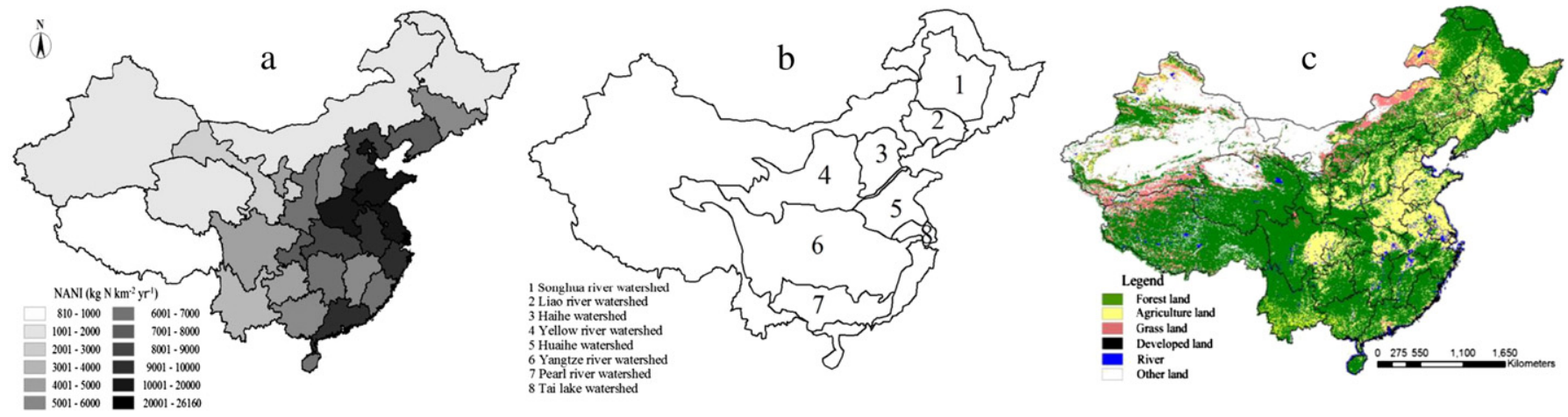

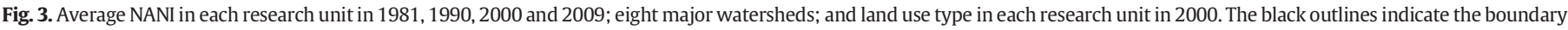

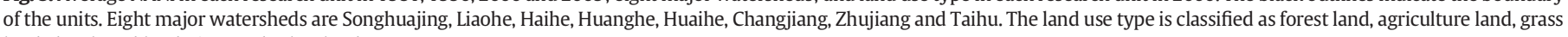
land, developed land, river and other land.

28 years, followed by Tianjin (14131 $\mathrm{kg} \mathrm{N} \mathrm{km}^{-2} \mathrm{yr}^{-1}$ ) and Jiangsu (13983 $\mathrm{kg} \mathrm{N} \mathrm{km}^{-2} \mathrm{yr}^{-1}$ ).

\subsection{Spatial variation of NANI}

Fig. 3a shows the geographic difference of NANI average in 1981, 1990, 2000 and 2009. NANI is higher in southeast Mainland China than in northwest Mainland China. The southeast is mainly covered by agricultural and developed land, while the northwest is mainly covered by forest and desert (see Fig. 3c). Economy develops rapidly in the southeast, so it has a greater population density and a higher gross domestic product (GDP). Thus, NANI in the southeast is higher. Fig. 3a also shows that Shanghai has the largest NANI of $26160 \mathrm{~kg} \mathrm{~N} \mathrm{~km}^{-2} \mathrm{yr}^{-1}$. Over the past 28 years, the average NANI was $3791 \mathrm{~kg} \mathrm{~N} \mathrm{~km}^{-2} \mathrm{yr}^{-1}$ in Mainland China.

Fig. 3b shows China's eight major watersheds. Compared with Fig. 3a and $c$, these watersheds almost cover all those areas that have greater NANI, and these areas are covered by cultivated lands and developed lands. Therefore, these eight major watersheds have the most serious water pollution in China. The administrative regions of watershed 3 (Haihe watershed), watershed 5 (Huaihe watershed) and watershed 8 (Tai lake watershed) have greater NANI.

\subsection{Change in NANI sources}

The sources of NANI in Mainland China in different years were analyzed (see Table 6). N input of fertilizer is the largest source of NANI, followed by atmospheric $\mathrm{N}$ deposition and $\mathrm{N}$ fixation. $\mathrm{N}$ fertilizer use had an upward trend from $42.4 \%$ (1000 $\mathrm{kg} \mathrm{N} \mathrm{km}^{-2} \mathrm{yr}^{-1}$ ) to $60.6 \%$ (3040.4 $\mathrm{kg} \mathrm{N} \mathrm{km}^{-2} \mathrm{yr}^{-1}$ ) of NANI from 1981 to 2009, but the cultivated area increased merely from $9.90 \times 10^{5} \mathrm{~km}^{2}$ to $12.17 \times 10^{5} \mathrm{~km}^{2}$. As can be seen, fertilizer use per unit area had a sharp increase.

Over the past 28 years, value of atmospheric $\mathrm{N}$ deposition increased (from 677.kg N km${ }^{-2} \mathrm{yr}^{-1}$ to $1363 \mathrm{~kg} \mathrm{~N} \mathrm{~km}^{-2} \mathrm{yr}^{-1}$ ), indicating the atmospheric environmental deterioration that may be caused by fertilizer volatilization, automobile exhaust and so on. However, its percentage changed slightly due to more rapid increase of NANI.

Net $\mathrm{N}$ in human food and animal feed is proportional to the human population and animal number. In Table 6 , the negative percentage values of $\mathrm{N}$ for human food and animal feed indicate that $\mathrm{N}$ output occurs.

China's population growth over the past 28 years leads to increase of $\mathrm{N}$ in human food from $306 \mathrm{~kg} \mathrm{~N} \mathrm{~km}^{-2} \mathrm{yr}^{-1}$ to $451 \mathrm{~kg} \mathrm{~N} \mathrm{~km}^{-2} \mathrm{yr}^{-1}$. However, the percentage values do not have significant change though $\mathrm{N}$ consumption per capita per year and total $\mathrm{N}$ consumption have a remarkable increase. This is because the agricultural food products and animal products also increased.

$\mathrm{N}$ fixation and $\mathrm{N}$ content in seed are related to land use. Over the past 28 years, there were some change in land use, but the value of $\mathrm{N}$ fixation and $\mathrm{N}$ content in seed changed insignificantly.

Change in NANI sources in the 31 research units over the past 28 years is shown in Table 7. $\mathrm{N}$ fertilizer use has the biggest change in these research units except Beijing, Shanghai, Tibet and Qinghai. Beijing and Shanghai are the most densely populated cities in China, and population change in these two cities is the most important factor for the change in NANI. Tibet and Qinghai have low population density and fewer areas of cultivated land but larger areas of desert, so the change in NANI in these two research units is mainly affected by atmospheric deposition.

\section{Discussion}

\subsection{Relational analysis between socioeconomic factors and NANI}

Grey relational grade analysis was conducted between the socioeconomic factors (gross domestic product, gross agricultural output value, cultivated land area, total population density, agricultural population density, total fertilizer, total population and total grain yield) and

Table 6

Sources of $\mathrm{N}$ inputs and their change $\left(\mathrm{kg} \mathrm{N} \mathrm{km}^{-2} \mathrm{yr}^{-1}\right)$. The symbol "-" means contribution to NANI reduction.

\begin{tabular}{|c|c|c|c|c|c|c|c|c|c|c|}
\hline \multirow[t]{2}{*}{ Year } & \multirow{2}{*}{$\begin{array}{l}\text { Atmospheric } \\
\mathrm{N} \text { deposition }\end{array}$} & \multirow[t]{2}{*}{$\mathrm{N}$ fertilizer use } & \multicolumn{5}{|c|}{$\mathrm{N}$ in human food and animal feed } & \multirow[t]{2}{*}{ N fixation } & \multirow{2}{*}{$\begin{array}{l}\mathrm{N} \text { content } \\
\text { of the seed }\end{array}$} & \multirow[t]{2}{*}{ NANI } \\
\hline & & & $\begin{array}{l}\text { Food consumption } \\
\text { of human }\end{array}$ & $\begin{array}{l}\text { Feed consumption } \\
\text { of animal }\end{array}$ & $\begin{array}{l}\text { Animal production for } \\
\text { human consumption }\end{array}$ & $\begin{array}{l}\text { Crop } \\
\text { production }\end{array}$ & Total & & & \\
\hline 1981 & $677(28.7 \%)$ & $1000(42.4 \%)$ & 306 & 395 & 243 & 495 & $-37(-1.6 \%)$ & $711(30.1 \%)$ & $9(0.4 \%)$ & 2360 \\
\hline 1990 & $897(26.5 \%)$ & $1842(54.4 \%)$ & 437 & 500 & 304 & 705 & $-71(-2.1 \%)$ & $709(20.9 \%)$ & $10(0.3 \%)$ & 3388 \\
\hline 2000 & $1142(26.0 \%)$ & $2592(58.9 \%)$ & 509 & 607 & 373 & 817 & $-74(-1.7 \%)$ & $727(16.5 \%)$ & $13(0.3 \%)$ & 4401 \\
\hline 2009 & $1363(27.2 \%)$ & $3040(60.6 \%)$ & 553 & 528 & 337 & 869 & $-125(-2.5 \%)$ & $723(14.4 \%)$ & $13(0.3 \%)$ & 5013 \\
\hline Average & $1020(26.9 \%)$ & $2119(55.9 \%)$ & 451 & 508 & 314 & 722 & $-77(-2.0 \%)$ & $718(18.9 \%)$ & $11(0.3 \%)$ & 3791 \\
\hline
\end{tabular}


Table 7

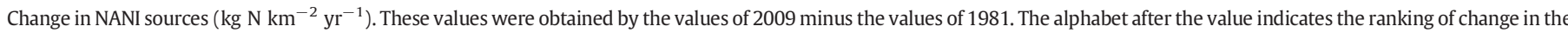
same row, wherein (a) indicates the greatest change, followed by (b) and (c). The symbol "-" means contribution to NANI reduction.

\begin{tabular}{|c|c|c|c|c|c|c|c|c|c|}
\hline \multirow[t]{2}{*}{ Name } & \multirow{2}{*}{$\begin{array}{l}\text { Atmospheric } \mathrm{N} \\
\text { deposition }\end{array}$} & \multirow[t]{2}{*}{$\mathrm{N}$ fertilizer use } & \multicolumn{5}{|c|}{$\mathrm{N}$ in human food and animal feed } & \multirow[t]{2}{*}{$\mathrm{N}$ fixation } & \multirow{2}{*}{$\begin{array}{l}\mathrm{N} \text { content } \\
\text { of tsathe seed }\end{array}$} \\
\hline & & & $\begin{array}{l}\text { Food consumption } \\
\text { of human }\end{array}$ & $\begin{array}{l}\text { Feed consumption } \\
\text { of animal }\end{array}$ & $\begin{array}{l}\text { Animal production for } \\
\text { human consumption }\end{array}$ & $\begin{array}{l}\text { Crop } \\
\text { production }\end{array}$ & Total & & \\
\hline Beijing & 1706(b) & 932(c) & 2661(a) & -125 & 90 & 329 & 2954 & -59 & -13 \\
\hline Tianjin & 2456 (b) & $10228(a)$ & $2241(\mathrm{c})$ & 542 & -450 & -885 & 1448 & -9 & 8 \\
\hline Hebei & 1344(b) & $6960(a)$ & $674(c)$ & 498 & -315 & -1397 & -540 & -9 & 13 \\
\hline Shanxi & 1957(b) & 2038(a) & 405(c) & -92 & 23 & -438 & -102 & 5 & 2 \\
\hline Inner Mongolia & 382(b) & 788(a) & 36 & $89(c)$ & -44 & -235 & -154 & 9 & 1 \\
\hline Liaoning & 1307(b) & $2450(a)$ & 466 & $583(c)$ & -335 & -455 & 259 & 13 & 2 \\
\hline Jilin & 952(b) & $3814(a)$ & 231 & 463(c) & -242 & -1160 & -708 & 39 & 5 \\
\hline Heilongjiang & 425(b) & 1435(a) & 128 & $243(c)$ & -141 & -1293 & -1063 & 34 & 3 \\
\hline Shanghai & 3244(b) & 2155(c) & $5177(a)$ & -629 & 587 & 620 & 5755 & -66 & -7 \\
\hline Jiangsu & 2349(b) & 11862(a) & $1242(c)$ & -224 & 134 & -1401 & -249 & 6 & 16 \\
\hline Zhejiang & 978(b) & 1486(a) & 887(c) & -204 & 112 & 656 & 1452 & 5 & -1 \\
\hline Anhui & 1381(b) & 7466(a) & 712(c) & -18 & -107 & -1490 & -904 & 46 & 24 \\
\hline Fujian & $1160(b)$ & 2458(a) & $564(c)$ & 228 & -245 & 211 & 759 & 2 & 0 \\
\hline Jiangxi & 1197(b) & 1978(a) & 481(c) & 253 & -199 & -574 & -39 & 9 & 1 \\
\hline Shandong & $1790(b)$ & 8278(a) & $1029(c)$ & 623 & -415 & -1980 & -743 & 9 & 26 \\
\hline Henan & 2253(b) & 15157(a) & 981 & $1663(c)$ & -1215 & -2965 & -1536 & 24 & 43 \\
\hline Hubei & 1171(b) & 7678(a) & $482(c)$ & 360 & -312 & -536 & -5 & 25 & 5 \\
\hline Hunan & 1069(b) & $3162(a)$ & 467 & $676(c)$ & -562 & -473 & 108 & 9 & 1 \\
\hline Guangdong & 1713(b) & $3365(a)$ & $1182(c)$ & -775 & 621 & 800 & 1827 & -10 & -1 \\
\hline Guangxi & 1468(b) & $2674(a)$ & $371(\mathrm{c})$ & -526 & 310 & -260 & -105 & 33 & 5 \\
\hline Hainan & 1584(b) & 4825(a) & $508(c)$ & -720 & 393 & 102 & 282 & 39 & 6 \\
\hline Chongqing & 1795(b) & 4079(a) & $432(c)$ & 220 & -213 & -646 & -206 & -10 & -3 \\
\hline Sichuan & 960(b) & $1812(a)$ & 238 & $290(c)$ & -198 & -233 & 97 & -1 & 0 \\
\hline Guizhou & 946(b) & 2151(a) & 391 & 406(c) & -274 & -492 & 31 & 75 & 11 \\
\hline Yunnan & 927(b) & 2259(a) & 230 & 305(c) & -223 & -400 & -88 & 42 & 6 \\
\hline Tibet & 77(a) & $17(\mathrm{c})$ & 5 & 19(b) & -6 & -3 & 15 & 1 & 0 \\
\hline Shaanxi & 1657(b) & 4010(a) & $324(c)$ & 29 & -52 & -387 & -86 & 6 & 1 \\
\hline Gansu & $570(b)$ & 908(a) & 120 & 131(c) & -62 & -198 & -10 & 14 & 2 \\
\hline Qinghai & 41(a) & 31(b) & $15(c)$ & -23 & 6 & -11 & -12 & 0 & 0 \\
\hline Ningxia & 1323(b) & 3423(a) & 265 & $266(c)$ & -127 & -647 & -243 & 22 & 4 \\
\hline Xinjiang & 162(b) & 459(a) & $29(c)$ & 19 & -11 & -109 & -71 & 3 & 1 \\
\hline Mainland China & $685(b)$ & 2041(a) & $246(c)$ & 133 & -93 & -374 & -88 & 12 & 4 \\
\hline
\end{tabular}

NANI calculation with a discrimination coefficient $(\rho)$ of 0.5 . The results are as follows (see Table 8):

$\mathrm{X}_{4}>\mathrm{X}_{9}>\mathrm{X}_{3}>\mathrm{X}_{6}>\mathrm{X}_{7}>\mathrm{X}_{5}>\mathrm{X}_{1}>\mathrm{X}_{8}>\mathrm{X}_{2}$

The primary factor in relation to the change in NANI is total population density, followed by total grain yield and cultivated land area. Among all of the factors, total population density, total population and agricultural population density are main social factors and their relational grades are $0.9235,0.8098$ and 0.8027 , respectively. Total population density has the greatest relational grade, indicating that change in NANI is mainly determined by the total population density. Cultivated land area, total grain yield and total fertilizer use are main agricultural factors and their relational grades are $0.8706,0.8710$ and 0.8426 , respectively. As can be seen, cultivated land area has the greatest relational grade, indicating that among the agricultural factors, cultivated land area is a main factor in relation to the change in NANI. Gross domestic product and gross agricultural output value are main economic factors and their relational grades are 0.7985 and 0.6984 , respectively. Gross domestic product has a greater relational grade, so it is the closest economic factor in relation to NANI change in this study.

\subsection{Vary of per capita food consumption}

As shown in Table 9, from 1980 to 2009, the grain and vegetable consumption increased firstly and then decreased, while the consumption of meat, egg, milk and aquatic product showed an increasing trend, indicating that the diet of Chinese people was gradually changing from a simply adequate meal type to a nutritious meal type, which leads to NANI change. In the densely populated major cities, such as Beijing and Shanghai, and their corresponding watersheds, population growth and diet habit change are the most importance factors for rapid increase of NANI (see Table 7). A large amount of $\mathrm{N}$ input leads to regional eutrophication. Therefore, the most effective way for solving the problem of high level of $\mathrm{N}$ input is to reasonably allocate the social resources to reduce the existing population density. Meanwhile, the decline in population density is also helpful for reduction in non-food $\mathrm{N}$ input, such as vehicle exhaust, feces evaporation, etc., and therefore objectively reduces atmospheric $\mathrm{N}$ deposition. In addition, more reasonable and nutrient diet may also contribute to the reduction of $\mathrm{N}$ input.

Table 8

Grey relational grade analysis.

\begin{tabular}{|c|c|c|c|c|c|c|c|c|c|}
\hline & $\begin{array}{l}\text { Gross domestic } \\
\text { product }\end{array}$ & $\begin{array}{l}\text { Gross agricultural } \\
\text { output value }\end{array}$ & $\begin{array}{l}\text { Cultivated land } \\
\text { area }\end{array}$ & $\begin{array}{l}\text { Total population } \\
\text { density }\end{array}$ & $\begin{array}{l}\text { Agricultural population } \\
\text { density }\end{array}$ & $\begin{array}{l}\text { Total } \\
\text { fertilizer }\end{array}$ & $\begin{array}{l}\text { Total } \\
\text { population }\end{array}$ & Total area & $\begin{array}{l}\text { Total grain } \\
\text { yield }\end{array}$ \\
\hline & $\mathrm{X}_{1}$ & $\mathrm{X}_{2}$ & $\mathrm{X}_{3}$ & $\mathrm{X}_{4}$ & $\mathrm{X}_{5}$ & $\mathrm{X}_{6}$ & $X_{7}$ & $\mathrm{X}_{8}$ & $\mathrm{X}_{9}$ \\
\hline Relational grade & 0.7985 & 0.6984 & 0.8706 & 0.9135 & 0.8027 & 0.8426 & 0.8098 & 0.7274 & 0.8710 \\
\hline
\end{tabular}


Table 9

Per capita consumption food $(\mathrm{kg})$.

\begin{tabular}{lrrrr}
\hline & \multicolumn{1}{c}{1980} & \multicolumn{1}{c}{1990} & \multicolumn{1}{c}{2000} & \multicolumn{1}{c}{2009} \\
\hline Crop & 219.00 & 262.08 & 250.23 & 232.00 \\
Vegetable & 83.00 & 134.00 & 106.74 & 98.44 \\
Meat & 11.08 & 12.59 & 18.30 & 21.53 \\
Egg & 1.03 & 2.41 & 4.77 & 5.32 \\
Milk & 0.52 & 1.10 & 1.06 & 3.60 \\
Aquatic product & 0.89 & 2.13 & 3.92 & 5.27 \\
\hline
\end{tabular}

\subsection{Grain yield}

World-wide agricultural development has proved that fertilizer application is the most effective and important means for increasing production. China is an intensive-agriculture country, and agricultural production is highly dependent on fertilizer application (Chen et al., 2007; Li et al., 1998). The cultivated land area in China is $1 / 7$ of the total of the world, but its fertilizer application accounts for $1 / 3$ of the total, ranking first in the world. In this study, the total grain yield in 2009 was 1.62 times that in 1981, while the amount of applied fertilizer was 4.04 times (see Table 10). Grain yield per unit mass of fertilizer showed an obvious downward trend, indicating that the amount of applied fertilizer per unit weight of grain was gradually increasing, i.e., the fertilizer utilization efficiency was gradually reducing. Low fertilizer utilization efficiency may decline soil fertility, degrade crop quality and lead to serious environmental pollution. Therefore, in those agriculture-dominated research units and watersheds, it is significant to improve fertilizer utilization efficiency in agriculture because in these units it is the most effective way for reducing NANI and is one of the most important means for mitigating nutrient point source pollution.

\subsection{Method for improving fertilizer utilization efficiency}

China is facing harsh problems of growing population, shrinking arable land and increasing food demand. Maximization of fertilizer utilization efficiency is extremely important for food security and ecological environment protection (Hu and Li, 2005; Yan et al., 2008). At present, the main techniques and methods are: 1 . fertilizing accurately in accordance with the farmland nutrients and promoting formulated fertilization technology; 2. developing organic fertilizers; and 3. improving the methods of fertilizing. Firstly, based on the rule of fertilizer requirement of crops, soil testing results and fertilizer utilization efficiency, the amount of fertilizer is reasonably adjusted to supply the crop with comprehensive and reasonable nutrients so as to maximize the crop's potential in increasing yield, thereby improving economic efficiency (Gao and Lü, 2006; He et al., 2007; Liu et al., 2006; Peng et al., 1996, 2002). Secondly, the majority of nitrogen-supplying organic fertilizers contain insoluble nitrogen and act as a slow-release fertilizer, so they can increase physical and biological nutrient storage mechanisms in soils and mitigate risks of over-fertilization. Organic fertilizer nutrient content, solubility, and nutrient release rates are typically much lower than mineral (inorganic) fertilizers (Du et al., 2005). A University of North Carolina study found that potential mineralizable nitrogen (PMN) in the soil was $182-285 \%$ higher in organic mulched systems than in the

Table 10

Grain yield per unit mass of fertilizer.

\begin{tabular}{llllll}
\hline Year & $\begin{array}{l}\text { Total } \\
\text { fertilizer } \\
\left(10^{7} \mathrm{~kg}\right)\end{array}$ & $\begin{array}{l}\text { Fertilizer N } \\
\left(10^{7} \mathrm{~kg}\right)\end{array}$ & $\begin{array}{l}\text { Total grain } \\
\text { yield } \\
\left(10^{7} \mathrm{~kg}\right)\end{array}$ & $\begin{array}{l}\text { Grain yield } \\
\text { per unit mass } \\
\text { of fertilizer } \\
\left(\mathrm{kg} \cdot \mathrm{kg}^{-1}\right)\end{array}$ & $\begin{array}{l}\text { Grain yield } \\
\text { per unit mass } \\
\text { of fertilizer N } \\
\left(\mathrm{kg} \cdot \mathrm{kg}^{-1}\right)\end{array}$ \\
\hline 1981 & 1334.9 & 950.3 & 32502.0 & 24.3 & 34.2 \\
1990 & 2590.3 & 1751.1 & 44624.3 & 17.2 & 25.5 \\
2000 & 4146.4 & 2464.5 & 46217.5 & 11.1 & 18.8 \\
2009 & 5390.6 & 2890.4 & 52657.9 & 9.8 & 18.2 \\
\hline
\end{tabular}

synthetics control (Do et al., 2013; Tu et al., 2006). Thirdly, according to the specific fertilizer demand, crop should be fertilized reasonably in different growth stages to satisfy the nutrient demand at each stage so as to achieve the purpose of economic fertilization (Jess, 2004; Lu and Wu, 2004; Wang, 2002; Yu and Zhang, 2006). Deep application of fertilizer also needs to be promoted to minimize the loss of fertilizer and improve fertilizer utilization efficiency.

\subsection{Fate of NANI}

There is a high level of $\mathrm{N}$ input in Mainland China every year. But, where has it gone? Part of it is deposited in plants and animals. $\mathrm{N}$ is essential for animals and plants as it is an important component of nucleic acid in animals and is indispensable for photosynthesis and respiration in plants. Part of it is deposited in soil. After a fertilizer is applied into soil, plant retains no more than $50 \%$ of the fertilizer (Wang et al., 2010), and the rest of the fertilizer is deposited in soil, resulting in many environmental problems such as soil compaction (Gregorich et al., 2011; Jordan et al., 2003; Ruser et al., 2006). Part of it is input in groundwater. $\mathrm{N}$ accumulated in the soil infiltrates into the groundwater or flows in runoff to rivers and streams. The other part $\mathrm{N}$ in human excretion flows through sewers into rivers. $\mathrm{N}$ in groundwater and rivers leads to eutrophication and causes loss of ecological functions of water, thereby resulting in serious environmental problems such as the death or even extinction of aquatic animals and plants. For example, $56 \%$ of the Yangtze River Estuary and its subsidiaries have been heavily polluted due to high $\mathrm{N}$ concentration (Quan et al., 2005). Algal blooms frequently occurred in recent years in Taihu Lake, located at the lower reaches of the Yangtze River (Qin et al., 2007). These environmental problems are thought to be directly related to the increased $\mathrm{N}$ export to water bodies (Xu et al., 2009).

By the end of 2009, 53.2\% of household sewage in Mainland China could be treated by sewage treatment plants (Zhou, 2010). After the treatment, $90 \%$ of sewage $\mathrm{N}$ was left in the sludge and would eventually be landfilled. In recent years, researches on re-use of sewage sludge are being conducted (e.g., used as agricultural fertilizer or used for biogas production), but they have not yet been applied on a large scale (Xiong and Zhang, 2007).

\section{Conclusion}

In mainland China, NANI has increased with time over the past 28 years, and it is higher in the southeast than in the northwest. $\mathrm{N}$ input of fertilizer is the largest source of NANI, followed by atmospheric $\mathrm{N}$ deposition and $\mathrm{N}$ fixation. China's eight major watersheds are located in the densely populated areas and cultivated areas, and these areas coincide with those areas that have higher NANI. Haihe watershed, Huaihe watershed and Tai lake watershed have the largest NANI. The primary factor in relation to the change in NANI is total population density, followed by cultivated land area and total grain yield. In those densely populated large cities, human N consumption contributes the most to the NANI change, so the most effective way to address the problem of high level of $\mathrm{N}$ input is to rationally allocate the social resources to reduce the existing population density. In those agriculture-dominated regions, increase in the amount of applied fertilizers is the most important factor causing increase in NANI, the most effective way for reducing NANI in these regions is to improve fertilizer utilization efficiency in agriculture.

\section{Acknowledgments}

Funding for this work was supported by the National Natural Science Foundation of China (Grant No. 51239009 \& 51309008). 


\section{References}

Agricultural Technology Promotion Center of China, 1999. Organic Fertilizer Nutrient of China. China Agriculture Press, Beijing, China.

Asman, W.A.H., Sutton, M.A., Schjorring, J.K., 1998. Ammonia: emission, atmospheric transport and deposition. New Phytologist 139, 27-48.

Battye, R., Battye, W., Overcash, C., 1994. Development and Selection of Ammonia Emission Factors. Final Report Prepared by EC/R Incorporated for EPA Atmospheric Research and Exposure Assessment Lab EPA Contract Number 68-D3-0034.

Bohlool, B., Ladha, J., Garrity, D., George, T., 1992. Biological nitrogen fixation for sustainable agriculture: a perspective. Plant and Soil 141, 1-11.

Bristow, C.E., Morin, A., Hesslein, R.H., 2008. Phosphorus budget and productivity of an experimental lake during the initial three years of cage aquaculture. Canadian Journal of Fisheries and Aquatic Sciences 65, 2485-2495.

Burns, R.C., Hardy, R.W.F., 1975. Nitrogen fixation in bacteria and higher plants. Soil Science $122,126-135$.

Chen, T.B., Zeng, X.B., Hu, Q.X., 2007. Utilization efficiency of chemical fertilizers among different counties in China. Acta Geographical Sinica 57, 531-538.

Da, P., 2013. Industrial upgrading, from start to reduce waste. Food and Beverage Industry $1,11-13$.

Do, C., Janaina, B., Filoso, S., Zotelli, L.C., 2013. Infield greenhouse gas emissions from sugarcane soils in Brazil: effects from synthetic and organic fertilizer application and crop trash accumulation. Global Change Biology Bioenergy 5, 267-280.

Dou, X.T., 1989. Biological Nitrogen Fixation. Beijing Agriculture Press, Beijing, China 52-54.

Du, J.J., Wang, X.A., Liao, Z.W., Tian, J.L., Chen, J.H., 2005. Effects of different extract conditions on water dissolution rate of coated controlled/slowed release fertilizer. Plant Nutrition and Fertilizer Science 11, 71-78.

Gao, F.J., Lü, J.L., 2006. Effect of urease deeply applied on wheat yield and fertilizer use efficiency. Shandong Agricultural Science 6, 49-50.

Gregorich, E.G., Lapen, D.R., Ma, B.L., 2011. Soil and crop response to varying levels of compaction, nitrogen fertilization, and clay content. Soil Society of America Journal $75,1483-1492$.

Guan, W., Sun, M., Lu, Y., 2011. Changes of regional environment quality pattern in China since 1986-2008. Journal of Environmental Sciences 32, 609-618.

Han, H., Bosch, N., Allan, J.D., 2011. Spatial and temporal variation in phosphorus budgets for 24 watersheds in the Lake Erie and Lake Michigan basins. Biogeochemistry 102, 45-58.

Han, Y., Yu, X., Wang, X., Wang, Y., Tian, J., Xu, L., Wang, C., 2013. Net anthropogenic phosphorus inputs (NAPI) index application in Mainland China. Chemosphere 90, 329-337.

He, F., Huang, J.L., Cui, K.H., Zeng, J.M., Xu, B., Peng, S.B., Buresh, R.J., 2007. Effect of real time and site specific nitrogen managements on rice yield and quality. Scientia Agricultural Sinica 40, 123-132.

Hu, L.J., Li, T.L., 2005. Questions and countermeasures in the development of precision agriculture. Journal Shenyang Agricultural University 7, 400-402.

Hu, Z., Yuan, J., Hu, Z., 2011. Study on China's low carbon development in an economyenergy-electricity-environment framework. Energy Policy 39, 2596-2605.

Hu, X.M., Zhang, J.Y., Zhang, G., 2012. Food waste management in China: status, problems and solutions (in Chinese). Acta Ecologica Sinica 32, 4575-4584.

Hutchings, N.J., Sommer, S.G., Andersen, J.M., 2001. A detailed ammonia emission inventory for Denmark. Atmospheric Environment 35, 1959-1968.

Jess, L.D., 2004. Precision Agriculture. A Bird's Eye View of Precision Agriculture. Wageningen Academic Press, Wageningen, pp. 8-10.

Jordan, T.E., Weller, D.E., 1996. Human contributions to terrestrial nitrogen flux. Bioscience $46,655-664$.

Jordan, D., Ponder, F., Hubbard, V.C., 2003. Effects of soil compaction, forest leaf litter and nitrogen fertilizer on two oak species and microbial activity. Applied Soil Ecology 23, 33-41.

Leeben, A., To nno, R., Freiberg, V., 2008. History of anthropogenically mediated eutrophication of Lake Peipsi as revealed by the stratigraphy of fossil pigments and molecular size fractions of pore-water dissolved organic matter. Hydrobiologia 599, 49-58.

Li, J., 2007. Animal Nutrition and Feed. Chongqing University Press, Chongqing, China.

Li, Q.K., Zhu, Z.L., Yu, T.R., 1998. Fertilizer Questions in Sustainable Development of Agriculture in China. Jiangxi Science and Technology Press, Nanchang, China.

Liang, C.H., 1999. Common Fertilizers and Their Application Techniques. Shengyang Press, Shengyang, China.
Liu, L.J., Xu, W., Sang, D.Z., Liu, C.L., Zhou, J.L., Yang, J.C., 2006. Site specific nitrogen management increases fertilizer nitrogen use efficiency in rice. Acta Agronomica Sinica 32, 987-994.

Liu, S.M., Zhu, B.D., Zhang, J., 2010. Environmental change in Jiaozhou Bay recorded by nutrient components in sediments. Marine Pollution Bulletin 60, 1591-1599.

Lowrance, R.R., Leonard, R.A., Asmussen, L.E., 1985. Nutrient budgets for agricultural watersheds in the southeastern coastal plain. Ecology 66, 287-296.

Lu, X.L., Wu, Q.Z., 2004. Extension of intellectualization precision fertilization in Guangxi. China Agricultural Technology Extension 1, 6-7.

McIsaac, G.F., David, M.B., Gertner, G.Z., 2001. Nitrate flux in the Mississippi River. Nature 414, 166-167.

Neset, T.S.S., Bader, H.P., Scheidegger, R., 2008. The flow of phosphorus in food production and consumption - Linkoping, Sweden, 1870-2000. Science of the Total Environment 396, 111-120.

Peng, S.B. Garcia, F.V. Laza, R.C. Sanico, A.L, Visperas, R.M. Cassman, K.G, 1996. Increased $\mathrm{N}$-use efficiency using a chlorophyll meter on high yielding irrigated rice. Field Crops Research 47, 243-252.

Peng, S.B., Huang, J.L., Zhong, X.H., Yang, J.C., Wang, G.H., Zou, Y.B., Zhang, F.S., Zhu, Q.S Bureshl, R., Wittl, C., 2002. Research strategy in improving fertilizer nitrogen use efficiency of irrigated rice in China. Scientia Agricultural Sinica 35, 1095-1103.

Qin, B.Q., Xu, P.Z., Wu, Q.L., 2007. Environmental issues of Lake Taihu. China Hydrobiology $581,3-14$

Quan, W.M., Shen, X.Q., Han, J.D., 2005. Analysis and assessment on eutrophication status and developing trend in Changjiang Estuary and adjacent sea. Marine Environmental Research 24, 13-16.

Rivera, E.C., Queiroz, J.F., Ferraz, J.M., 2007. Systems models to evaluate eutrophication in the Broa Reservoir, Sao Carlos, Brazil. Ecological Modelling 202, 518-526.

Ruser, R., Flessa, H., Russow, R., 2006. Emission of $\mathrm{N}_{2} \mathrm{O}, \mathrm{N}^{-2}$ and $\mathrm{CO}_{2}$ from soil fertilized with nitrate: effect of compaction, soil moisture and rewetting. Soil Biology and Biochemistry 38, 263-274.

Russell, M.J., Weller, D.E., Jordan, T.E., 2008. Net anthropogenic phosphorus inputs: spatial and temporal variability in the Chesapeake Bay region. Biogeochemistry 88, 285-304.

Su, C.G., Yin, B., Zhu, Z.L., Shen, Q.R., 2005. Farmland nitrogen loss and gaseous atmospheric nitrogen wet deposition and its environmental effects. Soils 37, 113-120.

Ti, C.P., 2011. Regional Nitrogen Budget at Different Spatial Scales. Nanjing Agricultura University, China 105-107.

Ti, C.P., Pan, J.J., Xia, Y.Q., Yan, X.Y., 2012. A nitrogen budget of mainland China with spatial and temporal variation. Biogeochemistry 108, 381-394.

Tu, C., Jean, B.R., Hu, S., 2006. Soil microbial biomass and activity in organic tomato farming systems: effects of organic inputs and straw mulching. Soil Biology and Biochemistry $38,247-255$.

Van, H.H.H., 1998. Factors affecting manure quantity, quality, and use. Proceedings of the Mid-South Ruminant Nutrition Conference, Dallas-Ft. Worth, May 7-8, 1998. Animal. Nutrition. Council, Texas, pp. 201-209.

Wang, Y.F., 2002. Study on applying effect of hydroquinone in corn. Corn Science 10, 90-92.

Wang, Y.G., 2003. The brief introduction of the progress of food composition table in China. Acta Nutrition Sinica 25, 126-129.

Wang, X.B., Dai, K., Wang, Y., 2010. Nutrient management adaptation for dryland maize yields and water use efficiency to long-term rainfall variability in China. Agricultural Water Management 97, 1344-1350.

Wu, S.X., 2005. The Spatial and Temporal Change of Nitrogen and Phosphorus Produced by Livestock and Poultry \& Their Effects on Agricultural Non-point Pollution in China. The Chinese Academy of Agricultural Science, China 23-26.

Wu, Q., Zhou, W., Zhang, L., 2011. China's environment: challenges and solutions. Environmental Earth Sciences 64, 1503-1504.

Xiong, S., Zhang, S.D., 2007. Evaluation of land application of sewage sludge in Beijing. Journal of Hebei Institute of Architectural Science and Technology 25, 36-39.

Xu, H., Yang, L.Z., Zhao, G.M., Yin, S.X., Liu, Z.P., 2009. Anthropogenic impact on surface water quality in Taihu Lake Region, China. Pedosphere 19, 765-778.

Yan, X., Jin, J.Y., He, P., Liang, M.Z., 2008. Recent advances in technology of increasing fertilizer use efficiency. Scientia Agricultural Sinica 41, 450-459.

Yang, F., Li, R., Cui, Y., Duan, Y.H., 2010. Utilization and develop strategy of organic fertilizer resources in China. Soil and Fertilizer Sciences in China 4, 77-81.

Yu, G.H., Zhang, Y.Z., 2006. Yield and nutrition qualities of pakchoi as affected by three types of nitrification inhibitors. Chinese Journal of Soil Science 37, 737-740.

Zheng, C., 2011. Serious Food Waste Found in the Catering Sector in China (ChinaDaily News, in Chinese). www.chinadaily.com.cn/hqgj/jryw/2011-03-08/content_1957714.htm (Accessed October 15, 2012)

Zhou, W.J., 2010. Water resources and water investigation report in china. China Prices 3, 19-23. 